I 216

\title{
「企業内における铖手技療法のニーズ第3報」 企業内施術室利用状況アンケート結果の検討
}

中川友裕 ${ }^{1}$ 坂井 友実 ${ }^{2}$

1 （株）リクルートコスモス 管理本部 総務グループ、 ${ }^{2}$ 筑波技術短期大学

【はじめに】これまで著者らは本学会において、企業 内における手技療法の二ーズについて、利用者の情 報を元に分析、検討して来た。今回は、健康診断実 施の際、全従業員を対象に企業内施術室の利用に関 するアンケートを実施し、企業における銊尒手技療 法のニーズについて分析検討したので報告する。

【対象および方法】対象は、2004 年 5 月現在の全従 業員数 875 名とした。健康診断実施の際、予め配布 する調查表に加え「マッサージルームに関するアン ケート」を同封した。アンケートは健康診断実施の 際に回収した。

マッサージルームの利用に関するアンケートの問 はすべて選択形式になっており、上位 3 位までを順 に示した。また、健康診断の健康調查表より、「いつ も感じている症状」を上位 3 位まで順に示した。

【結果】1. マッサージルームに関するアンケートの 回収率は $59 \%$ 、有效解答率は $96.3 \%$ であった。

問 1-1、貴方はマッサージルームを利用したことが ありますか？「利用したことがある」44.4\% (215) 「利用してない $55.6 \%$ (269

問 1-2 利用したことがある」と解答した方への問 問 1-2-1 どんな時利用するか（複数解答有り）1） こり・痛みがあるとき $66.2 \%$ 、2) 疲れたとき $35.3 \%$ 、

3）ストレスを感じたとき $11.1 \%$

問 1-2-2 どのような効果があるか (複数回答有り) 1)こり・痛みが軽滅した $53.6 \% 、 2)$ リラックスで きた $35.7 \% 、 3 ）$ 疲労が軽減した $32.4 \%$

問 1-2-3 どれ位の頻度で利用したいか 1）月 2 回 $28.6 \%(58) 、 2)$ 月 1 回 $28.1 \%(57) 、 3)$ 週 1 回 $25.1 \%$ (51)

問 1-2-4 現在どれ位の頻度で利用しているか 1) その他 $62.5 \%(125) 、 2)$ 月 1 回 $27.5 \%(55) 、 3)$ 月 2 回 $6.5 \%(13)$
問 1-2-5 希望の頻度で利用できない理由は（複数 回答有り）1）時間が取れない $54.3 \% 、 2 ）$ 予約が取 れない $25.7 \% 、 3 ） そ の$ 他 $24.0 \%$

問 1-3 利用しないまたは利用できない理由はなに か（複数回答有り）1）時間が取れない $57.2 \% 、 2 ）$ 特につらくない $21.2 \% 、 3 ） そ の$ 他 $10.8 \%$

2. 健康調查表の回収率は $97.2 \%$ あった。「いつも 感じている症状」の有効解答率は $100 \%$ であった。 男性では、1) 頝局こり $22.7 \% 、 2)$ ストレス $15.7 \%$ 、 3）眼精疲労 $12.2 \%$ でった。女性では、1）頝肩こ

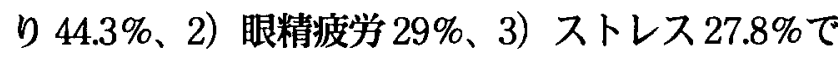
あった。

[考察およびまとめ】今回のアンケートでマッサージ ルームを「利用したことがある」と答えた者は $44.4 \%$ であった。この結果は、現在マッサージルームに従 業員の $46 \%$ のルテがあることから考えて、利用者 と非利用者の偏りは少なく、当社の銊・マッサージ のニーズを反映していると考えられる。

鍼・マッサージをどのような時に受け、どのような 効果を感じているかの問では、どちらも「こり・痛 み」が最も多くなっていた。これに対して、健康診 断の調查表でも「顏肩こり」が男女共に 1 位となつ ていた。また、マッサージルームの利用者が 4 割以 上であることを考えると、「こり・痛み」の対処法と して、銊负手技療法が貢献していることが示唆され る。また、希望の利用頻度と実際利用している頻度 に大きな差がでたのは、施術室が常設されていない 支社の影響が要因の一つとして考えられる。

「利用しないまたは「利用できない理由として、 6 割弱もの人が「時間がとれない」と答えているの は、就業時間中に 1 時間もの時間を作る難しさを示 していると思われる。 